\title{
STATUS NASAB ANAK LAHIR DI LUAR PERKAWINAN PERSPEKTIF HUKUM ISLAM DAN HAK ASASI MANUSIA
}

\author{
Ayu Indriani Amalia Martoredjo \\ Fakultas Syariah, Institut Agama Islam Negeri Manado, Indonesia \\ Email: ayunamartoredjo@gmail.com
}

\begin{abstract}
ABSTRAK
Nasab merupakan salah satu pengakuan syara sebagai garis keturunan dari pihak ayah di mana dari hubungan tersebut akan menimbulkan hak dan kewajiban seseorang dalam hal saling mewarisi, maka dari itu hasil penelitian yang penulis temukan dalam penelitian adalah Hak Asasi Manusia sangat melindungi hak-hak anak terlepas dari sah tidaknya status anak tersebut. Perlakuan diskriminasi kepada hak anak yang lahir di luar perkawinan tidak selaras dengan konsep Hak Asasi Manusia. Pasal 1 Deklarasi Universal Hak Asasi Manusia (DUHAM), yang menyebutkan bahwa semua orang dilahirkan merdeka dan mempunyai martabat serta hak-hak yang sama, mereka dikaruniai akal dan hati nurani dan hendaknya bergaul satu dengan yang lain dalam persaudaraan. Disamping itu pula bahwa Negara juga menghormati hak asasi manusia, termasuk hak asasi anak yang muncul karena adanya jaminan perlindungan dan pemenuhan. Hak Anak dalam Undang-Undang Dasar Negara Republik Indonesia Tahun 1945 dan beberapa ketentuan peraturan perundang-undangan baik yang bersifat nasional maupun yang bersifat internasional. Salah satunya adalah Undang-Undang Nomor 35 tahun 2014 tentang Perlindungan Anak.
\end{abstract}

Kata kunci: Nasab; Hak Asasi Manusia; Hukum Islam. 


\section{PENDAHULUAN}

Anak adalah titipan Tuhan untuk kedua orang tua, masyarakat, bangsa dan negara yang nantinya akan memajukan peradaban dunia, maka dari pengertian memberikan hak anak yang wajib diakui, diyakini, dan diamankan sebagai pelaksanaan amalan yang diterima orang tua, masyarakat, bangsa dan negara. (Lopa, 1996).

Anak menurut kamus Bahasa Indonesia adalah keturunan kedua sebagai konsekuensi dari hubungan antara laki-laki dan perempuan. Menurut Ensiklopedi Hukum Islam, pengertian anak adalah keturuna/n yang kedua dari seorang perempuan dan laki laki, atau orang yang lahir dari rahim seorang ibu, baik anak laki-laki atau anak perempuan atau khuntsa. (Husna, 2011).

Anak Menurut kedudukannya memiliki makna dari subsistem hukum yang ada dalam lingkungan perundang-undangan dan subsistem sosial kemasyarakatan universal. Pengertian anak dalam kedudukan hukum meliputi pengertian kedudukan anak dari pandangan sistem hukum sebagai subjek hukum. Pengertian anak secara etimologis dapat diartikan dengan manusia yang masih kecil ataupun manusia yang belum dewasa (Poerwadarmita, 1984). Menurut R.A. Kosnan "Anak-anak yaitu manusia muda dalam umur dalam jiwa dan perjalanan hidupnya karena mudah terpengaruh keadaan di sekitarnya (Koesnan, 2005).

Islam telah menentukan bahwa manusia menyelengarakan pernikahan karena pernikahan menjadi upaya untuk mendapatkan keturunan yang sah dengan cara pertalian nasab. Nasab adalah ikatan keluarga berawal dari ikatan darah dengan diberlangsungkannya akad nikah yang sah. Sedangkan ikatan anak dengan kedua orang tuanya tidak bakal berganti karena putusnya pernikahan orangtua dari si anak (Arifin, 1996).

Hukum Islam Menurut standarnya adalah memahami kedudukan anak yang lahir dari rahim ibunya, yakni anak yang resmi dan anak yang tidak (anak akibat dari perilaku zina). Anak yang resmi merupakan anak yang lahir sebab karena terjadinya pernikahan yang resmi selaras oleh ketentuan dan asasnya. Sebaliknya anak zina merupakan anak yang dilahirkan tanpa pernikahan yang resmi. Anak yang lahirnya sahih akibat hubungan pernikahan orang tuanya berlaku secara implusif memiliki ikatan nasab dengan ayah dan ibu kandung. Sedangkan anak yang tak mempunyai ikatan nasab atas ayah bila anak tersebut lahir dan kedua orang tuanya tidak melakukan pernikahan. Sementara menurut Islam, anak tidak cuma anugerah, tetapi selain itu dia dilambangkan sebagai titipan dari Allah swt. Semua anak yang dilahirkan sudah merekat kepada dia beraneka hak yang harus dijamin, orangtuanya ataupun negara. Keadaan ini memuat arti orang tua dan negara tidak dapat mengabaikan apalagi sampai melalaikan hak anak. Sebab 
mereka tidak sekadar merupakan harta keluarga namun mereka pula harta bangsa (Aimmah, 2010).

Bersumber pada Hukum Islam anak bakal mendapatkan haknya ketika terlaksananya aspek yang membuat orang tua wajib melaksanakan tanggung jawabnya bagi hak anaknya. Aspek yang penting adalah status atau nasab anak kepada keluarganya, aspek tersebut bersangkutan untuk hak anak demi mendapatkan warisan, nafkah serta perwalian.

Aliran Syafi'i berpandangan bahwa pengertian anak di luar pernikahan merupakan anak yang dilahirkaan kurang dari enam bulan sesudah terjadinya pernikahan seorang istri dengan suami yang sah, sampai melahirkan kejelasan kalau anak yang dilahirkan bukanlah anak dari suami yang resmi. Dijelaskan sama Ibnu Kasir dalam Tarjemahannya, maka Ali bin Abi Talib beralaskan dengan ayat Al-Qur'an mengenai batas minimal masa hamilnya sepanjang enam bulan, dalam Q.S Al- Ahqaf (46) : 15 dan juga dalam Q.S Luqman (31) :14.

Ayat diatas terdapat kepastian mengenai waktu minimal kehamilan, dikatakan maka waktu mengandung sampai waktu menyusui ialah tiga puluh bulan, atau dua tahun 6 bulan. Adapun dalam ayat kedua disebukan bahwa masa minimal menyapih adalah 2 tahun, maka waktu selama enam bulan ialah waktu minimal kehamilan, sebagaimana Ali bin Abi thalb berdalil dengan ayat di atas, serta disepakati oleh Usman bin Affan, serta para sahabat lainnya (Kasir, 1999).

Mahzab Hanafi berpendapat anak yang lahir di luar pernikahan yaitu anak yang dilahirkan kurang dari enam bulan setelah adanya akad perkawinan, sebagaimana pendapat imam Hanafi (Az-Zuhaili, n.d.). Sedang esensi Hukum atas ditentukannya nasab adalah berkat terjadinya hubungan bersama suami yang resmi, namun alasan yang nyata yaitu berkat terjadinya (Akad) pernikahan. Adapun persetubuhan adalah perkara yang terselubung, maka dengan adanya nikah menunjukan ditetapkannya nasab, sebagaimana sabda Nabi, Anak yang dahirkan adalah hak pemilik firasy, bagi pezina adalah batu sandungan (tidak mendapat apapun).

Berlangsungnya akad nikah diantara seorang laki laki dan perempuan, dan setelahnya mereka berjauhan daerah yang satu bertempat di utara dan yang lainnya selatan, dan sang ibu melahirkan anaknya, hingga nasab anak itu sabit kepada lelaki itu, walaupun tak mendapati asasnya yakni adanya hubungan badan, tetapi sudah terlihat asasnya yakni karena terjadinya perkawinan.(Al-kasaniy, 2003), Lalu paham mazhab Hanafi, maka yang dikatakan sebagai anak di luar pernikahan yaitu anak yang dilahirkan tidak lebih dari enam bulan sesudah terjadinya pernikahan. 
Perbedaan keduanya adalah mazhab Syafi'i mewajibkan terjadinya hubungan di antara suami istri yang resmi lalu sang istri melahirkan seorang bayi tidak lebih daripada enam bulan, padahal jika mengikuti mazhab Hanafi digenapkan melalui akad nikah, keadaan tersebut menjadi alasan yang jelas atas hubungan badan antara suami dan istri. Pada kejadian anak yang dilahirkan di luar pernikahan antara ulama berselisih pendapat mengenai status dan keterkaitannya mengenai hak anak itu.

Penganut mazhab Syafi'i beranggapan kalau nasab anak di luar pernikahan atas bapaknya berakhir, hingga status anak itu menjadi ajnabiyyah (orang lain), sebab itulah, bagi mazhab Syafi'i hingga anak itu bisa menikah dengan ayah kandungnya, sebab status anak itu menjadi orang luar (ajnabiyyah), juga bukan mahram dari ayah kandungnya. Bagi mazhab Syafi'i bukan dikecualin antara nasab yang sahih ataupun syar'i, hingga status nasab anak itu berakhir secara telak.

Mengenai keterkaitannya adalah berakhirnya segala hak yang berkaitan dengan nasab semacam hak waris, nafkah, dan hak wali, akan tetapi imam syafi'i melanjutkan bahwa anak yang lahir di luar nikah bisa mendapatkan warisan dari ayah kandungnya beserta ketentuan bahwa semua ahli warisnya anak tersebut mengakui dirinya, adanya seseorang yang membenarkan (mustalhiq) anak tersebut adalah anak dari seorang ayah yang meninggal dunia (pewaris), tak didapati kemungkinan nasab kecuali dari sang pewaris tersebut, maka pihak (mustalhiq) yang meluruskan nasab anak itu ialah orang yang sehat jasmani dan rohani serta sudah baliqh.

Madzab Hanafi berpendapat nasab anak yang lahir di luar pernikaahan terus sabit kepada ayah biologisnya, sebab pada dasarnya anak itu merupakan anak kandung dari sang ayah, anak dikatakan dari bapaknya sebab anak itu terlahir karena ayahnya, karenanya dilarang bagi seorang ayah kandung untuk menikahi anak di luar nikahnya tersebut. Nasab berdasarkan pendapat Syafi'i ialah berakhir, yang berkaitan pada ketiadaan kewajiban ayah kandung untuk memberi hak kepada anak, semacam pemberian nafkah, hak warisan ataupun hak wali sebab adanya nasab syar'i yaitu akan memastikan kewajiban pada ayah kandung dan ayah kandung akan menepati hak anaknya. Sementara itu aliran Hanafi memisahkan antara nasab mendasar atau hakiki, dan nasab hukum atau Syar'i. Sebagai nasab hakiki anak di luar pernikahan itu memang anaknya, ataupun sama artinya dengan darah dagingnya, karenanya di larang bagi ayah biologisnya untuk menikah dengan anaknya. Walaupun menurut nasab hakiki anak di luar pernikahan tetap sabit kepada ayah biologisnya, tetapi tidak ada keterkaitan segala sesuatu mengenai hak anak itu atas ayah kandungnya. 
Berdasarkan fiqh menurut terminologi anak yang sah ialah anak yang dilahirkan melalui akad nikah yang sah antara pria dan wanita. Sah tidaknya sang anak bakal ditentukan ikatan nasab dengan pria yang menjadi bapaknya. Nasab bisa terpentuk dan dimiliki dengan tiga cara, yakni melalui akad nikah yang resmi, melewati pernikahan yang fasid, dan dengan hubungan yang syubhat. (Az-Zuhaili, n.d.).

Menurut istilah fiqih tak ditemui sebutan "anak yang lahir di luar pernikahan”. Ulama fiqih memakai kata anak luar kawin dan juga anak muk'ah. Anak muk'ah atau anak zina ialah anak yang lahirnya menjadi dampak dari satu ikatan yang tidak sah. Ikatan tidak sah yakni ikatan antara dua orang yang belum menikah dan tidak melaksanakan tuntutan dan asasnya. (Makluf, 1979).

Anak yang dilahirkan di luar penikahan yang sah tidak hanya mendapatkan perlakuan diskriminasi juga memperoleh aib yang buruk dari masyarakat juga tak mendapatkan hak segalanya dari sisi ayah yang menghamili ibu, kemudian menimbulkan kondisinya jadi anak yang dilahirkan di luar nikah mau tidak mau menanggung dampak hukum dari perilaku orangtua nya yang berpengaruh kepada ketentraman hidup sang anak.

Menurut hukum perdata, anak luar pernikahan tak mempunyai kaitan perdata bersama bapaknya yang terkait pada putusnya hak kewarisannya, hak wali, nafkah dan lainnya pada sisi bapaknya. Seperti bunyi Undang-Undang No 1 tahun 1974 mengenai Pernikahan. Maka anak yang lahir di luar pernikahan sekedar memiliki ikatan perdata dengan ibunya. Dari hal tersebut, maka penulis membuat penelitian tentang "Status Anak yang lahir di luar penikahan yang sah yang berdasarkan pada konsep Hukum Islam dan Hak Asasi Manusia.

\section{METODE PENELITIAN}

Pelaksanaan penelitian ini penulis menggunakan penelitian kualitatif bersifat library research yaitu dengan melakukan analisis deskriptif dengan judul yang diangkat oleh penulis. Sedangkan metode analisis deskriptif atau metode yuridis normative yaitu suatu metode yang memberikan gambaran dan keterangan yang secara jelas, objektif, sistematis analitis dan kritis mengenai status nasab anak yang lahir di luar pernikahan yang terdapat dalam Hukum perdata, kompilasi hukum Islam serta dalam fiqh, atau dengan kata lain bahwa metode yuridis normative ini merupakan penelitian hukum kepustakaan yang dilakukan dengan cara meneliti bahan-bahan pustakaatau data sekunder belaka. Objek yang dianalisis dalam pendekatan yang bersifat kualitatif ini adalah metode penelitian yang mengacu pada norma-norma hukum yang terdapat peraturan perundang undangan 


\section{HASIL DAN PEMBAHASAN}

\section{Perlindungan Hak Asasi Manusia (HAM) terhadap Anak yang Lahir di Luar Pernikahan}

Deklarasi hak-hak anak kedua di tahun 1959, telah menyatakan bahwa umat manusia wajib memberikan yang terbaik kepada anak. Mukadimah nya yang berbunyi" karena alasan fisik dan mental yang belum matang dan dewasa, anakanak membutuhkan perlindungan serta perawatan khusus termasuk perlindungan hukum sebelum maupun sesudah mereka dilahirkan.

Hak Asasi Manusia tidak akan pernah mempunyai arti apapun bila tidak ditindak lanjuti dengan Hukum yang mengatur akan hubungan hak tersebut, artinya hukumlah yang mengformalkan hak asasi manusia kedalam seperangkat aturan-aturan untuk menjaga dan meliindungi agar tidak menjadi benturanbenturan dalam kehidupan bermasyarakat dan bernegara.

Perlakuan diskriminatif terhadap hak-hak anak luar kawin tidak selaras dengan prinsip konsep Hak Asasi Manusia. Pasal 1 Deklarasi Universal Hak Asasi Manusia (DUHAM), Disebutkan bahwa semua orang dilahirkan merdeka dan mempunyai martabat dan hak-hak yang sama, mereka dikaruniai akal dan hati nurani dan hendaknya bergaul satu dengan yang lain dalam persaudaraan. (PBB, 1948)

Pasal 2 berbunyi bahwa setiap orang berhak atas semua hak dan kebebasan yang tercantum di dalam Deklarasi ini dengan tidak ada pengecualian apapun, seperti pembedaan ras, warna kulit, jenis kelamin, Bahasa, agama, politik atau kedudukan lain. (PBB, 1948) Secara spesifik Pasal 25 ayar (2) DUHAM menyatakan bahwa ibu anak-anak berhak mendapatkan perhatian dan bantuan khusus, Semua anak, baik yang dilahirkan di dalam maupun di luar perkawinan, harus menikmati perlindungan sosial yang sama (Djamil, 2013). Deklarasi Hak Anak juga menghendaki bahwa anak hendaknya menikmati semua hak-haknya, tanpa diskriminasi karena alasan ras, warna kulit, jenis kelamin, bahasa, agama, pandangan politk atau pandangan lainnya, asal usul kebangsaan atau sosial, kekayaan, kelahian, atau status sosial lainnya, baik dirinya maupun keluarganya: setiap anak juga harus dilindungi dari setiap praktek diskriminasi berdasarkan rasial, agama, dan bentuk-bentuk lainnya. (Gultom, 2012)

Undang-Undang RI Tahun 1945 mengenai Hak Asasi Anak diatur dalam 28 B ayat (2) yang menyatakan bahwa setiap anak berhak atas kelangsungan hidup, tumbuh dan berkembang, serta memperoleh perlindungan dari kekerasan dan diskriminasi. Peraturan serupa ditemukan dalam Undang-Undang No 39 tahun 1999 Tentang Hak Asasi Manusia. Pasal 2 yang berbunyi bahwa Negara 
Republik Indonesia mengakui dan menjunjung tinggi Hak Asasi Manusia dan kebebasan dasar manusia sebagai hak yang secara kodrati melekat pada diri dan tak terpisahkan dari manusia, yang harus dilindungi, dihormati dan ditegakkan demi peningkatan martabat kemanusiaan, kesejahteraan, kebahagiaan, dan kecerdasan serta keadilan. Juga Pada Pasal 3 ayat (2) Setiap orang berhak atas pengakuan, Jaminan perlindungan dan perlakuan hukum yang adil serta mendapat kepastian hukum dan perlakuan yang sama di depan Hukum

Undang-Undang RI Tahun 1945 Mengenai Hak Asasi Anak diatur dalam $28 \mathrm{~B}$ ayat (2) yang menyatakan bahwa setiap anak berhak atas kelangsungan hidup, tumbuh dan berkembang, serta memperoleh perlindungan dari kekerasan dan diskriminasi. Peraturan serupa ditemukan dalam Undang-Undang No 39 tahun 1999 Tentang Hak Asasi Manusia. Pasal 2 yang berbunyi bahwa Negara Republik Indonesia mengakui dan menjunjung tinggi Hak Asasi Manusia dan kebebasan dasar manusia sebagai hak yang secara kodrati melekat pada diri dan tak terpisahkan dari manusia, yang harus dilindungi, dihormati dan ditegakkan demi peningkatan martabat kemanusiaan, kesejahteraan, kebahagiaan, dan kecerdasan serta keadilan. (Undang-Undang No. 39 Tahun 1999 Tentang Hak Asasi Manusia, n.d.) Juga Pada Pasal 3 ayat (2) Setiap orang berhak atas pengakuan, Jaminan perlindungan dan perlakuan hukum yang adil serta mendapat kepastian hukum dan perlakuan yang sama di depan Hukum.(Undang-Undang No. 39 Tahun 1999 Tentang Hak Asasi Manusia, n.d.)

Undang-Undang 23 Tahun 2002 sebagaimana telah diubah dengan Undang-Undang 35 Tahun 2004 tentang perlindungan anak menyatakan bahwa setiap orang dilarang memperlakukan anak secara diskriminatif yang mengakibatkan anak mengalami kerugian, baik materil maupun moril sehingga menghambat fungsi sosialnya.

Negara, Masyarakat, dan orang tua memiliki kewajiban mengupayakan perlindungan perlindungan terhadap anak agar proses tumbuh kembangnya tidak terganggu.(Undang-Undang Nomor 23 Tahun 2014 Tentang Perubahan Atas Undang-Undang No 23 Tahun 2002 Tentang Perlindungan Anak, n.d.) Tidak adanya pemisah antara anak yang sah dan anak luar kawin dalam berbagai instrument ham di atas, menunjukan bahwa setiap anak berhak atas pengakuan, jaminan, perlindungan dan perlakuan dan perlakuan hukum yang adil serta mendapat kepastian hukum dan perlakuan yang sama di depan hukum. Keberlakuan Pasal 43 Undang-Undang Perkawinan tidak selaras dengan prinsip kewajiban Negara berpartisipasi melalui undang-undang untuk menjamin pengakuan serta penghormatan atas hak hak dasar warga negaranya, Negara atau Pemerintah seharusnya memberi jaminan hak-hak keperdataan anak luar nikah melalui peraturan perundang-undangan 


\section{Perlindungan Hukum Anak yang Lahir di Luar Nikah di Indonesia}

Sejumlah ketentuan hukum dalam Hukum positif di Indonesia menentukan dan mengatur kedudukan hukum anak berdasarkan pada status hukum perkawinan dari kedua orang tuanya. Berdasarkan pada Pasal 1 KUHPerdata tersebut, hak hak keperdataan berbeda dengan hak-hak kenegaraan, walaupun pada dasarnya hakhak kenegaranan itu juga mengatur hak-hak keperdataan, Hak-Hak kenegaraan seperti hak sipil, hak ekonomi, hak politik, dan lain-lainnya yang menurunkan antara lain hak untuk dijamin persamaan kedudukan dihadapan hukum (equality before the law), berkaitan erat dengan hak keperdataan bahwa jaminan persamaan kedudukan dihadapan hukum berlaku bagi semua Orang, semua suku, semua agama, tanpa adanya ketentuan yang diskriminatif oleh negara dan praktiknya dalam masyarakat

Hak senantiasa berpasangan dengan kewajiban, hak memberi kenikmatan dan keleluasaan kepada individu dalam melaksanakannya, sedangkan kewajiban merupakan suatu pembatasan dan beban, sedangkan menurut Sri Soedewi Masjchoen Sofwan Hak merupakan hukum yang lain dan berada dalam wilayah hukum perdata. (Sofwan, 1981). Hak juga dapat dibedakan antara hak mutlak dan hak relative, dan yang termasuk hak mutlak ialah segala hak publik, yaitu: Hak menyatakan pikiran dan perasaan, dengan perantara pers; Hak-hak untuk mengajukan permohonan secara tertulis kepada yang berhak/ berwenang; Hak untuk memeluk dan menganut agama dan kepercayaannya masing masing secara bebas. Sedangkan sebagian dari hak keperdataan, adalah hak yang bersandar pada Hukum perdata dalam arti objektif, misalnya : Hak-hak kepribadian, Hak-hak keluarga, Hak benda, Hak hak kebendaan dan Hak-hak atas barang-barang tak berwujud.

Setiap anak harus mendapatkan perlindungan hukum, tidak terkecuali bagi anak yang di lahirkan di luar pernikahan, bila tidak demikian yang dirugikan adalah anak yang dilahirkan di luar perkawinan, padahal anak tersebut terlahir dalam kondisi suci dan tidak berdosa, sekalipun yang bersangkutan terlahir sebagai hasil zina. Anak yang dilahirkan di luar perkawinan seringkali mendapatkan perlakuan yang tidak adil dan stigma ditengah-tengah masyarakat.

Sehubungan dengan itu, dalam rangka memberikan perlindungan kepada anak yang di lahirkan di luar pernikahan serta mewajibkan laki-laki yang menyebabkan kelahirannya untuk bertanggung jawab, Mahkamah Konstitusi memutuskan aturan Hukum Pasal 43 ayat (1) Undang-Undang No 1 Tahun 1974 tentang Perkawinan bertentangan dengan Undang-Undang dasar 1945 secara bersyarat, yakni Inkonstitusional sepanjang ketentuan tersebut dimaknai menghilangkan hubungan perdata dengan laki-laki yang dapat dibuktikan berdasarkan ilmu pengetahuan dan teknologi, dan atau alat bukti lain menurut 
hukum mempunyai hubungan darah sebagai ayahnya, sehingga setiap anak yang dilahirkan di luar perkawinan tidak hanya mempunyai hubungan perdata dengan ibunya dan keluarga ibunya, melainkan juga termasuk mempunyai hubungan perdata dengan ayahnya dan keluarga ayahnya.

Peraturan Perundang-undangan mempunyai fungsi utama yaitu mempunyai sifat mengatur dan mengikat secara umum diantaranya adalah dengan menggunakan pendekatan filosofis (filsofis schegrondslag) sangat penting dan kegunaan untuk menghindari pertentangan peraturan perundang undangan yang disusun dengan nilai-nilai yang hakiki dan luhur di tengah-tengah masyarakat, misalnya etika, adat agama dan lain-lain. selain itu juga norma pembenaran (recht svaardiging) dikaji secara filosofis juga mempunyai alasan yang dapat dibenarkan apabila dipikirkan secara mendalam. Alasan tersebut sesuai dengan cita-cita dan pandangan hidup manusia dalam pergaulan hidup Bermasyarakat sesuai dengan cita-cita kebenaran (idee der waarheid), cita keadilan (idea der gerechtigheid) dan cita-cita kesusilaan (idiil der zedelijkheid.

\section{Perspektif Hukum Islam terhadap Anak Luar Pernikahan yang Sah}

Orang tua sebagai pihak pertama yang melindungi anak, mengenai hak dan Kewajiban mereka (orang tua) dalam Islam, kewajiban orang tua adalah menyayangi dan haknya adalah memperoleh penghormatan. Berbicara mengenai hak, pasti disisi lain ada kewajiban. Sebaliknya, kewajiban anak adalah penghormatan terhadap kedua orang tua dan haknya adalah memperoleh kasih sayang. Idealnya, prinsip ini tidak bisa dipisahkan. Artinya, seorang diwajibkan menghormati jika memperoleh kasih sayang. Dan orang tua diwajibkan menyayangi jika memperoleh kehormatan. Timbal balik, yang jika harus menunggu yang lain akan seperti telur dan ayam. Tidak ada satupun yang memulai untuk memenuhi hak yang lain. Padahal biasanya, seseorang mendapatkan hak jika telah melaksanakan kewajiban. Karena itu, yang harus di dahulukan adalah kewajiban. Tanpa memikirkan hak yang mesti diperoleh. Orang tua seharusnya menyayangi, dengan segala perilaku, pemberian dan perintah pada anaknya, selamanya. Bagitu juga anak, harus menghormati dan memuliakan orang tuanya, selamanya.

Akan tetapi dalam mengkritisi, putusan MK Nomor 46/PUU-VIII/2010 dinilai melanggar ajaran Islam dan tatanan hukum Islam. Dimana hukum Islam menyatakan bahwa, status anak yang lahir diluar pernikahan yang sah disamakan statusnya dengan anak zina dan anak li'an, oleh karena itu maka anak yang lahir di luar penikahan yang sah akan mempunyai akibat hukum sebagai berikut: (a). Tidak ada hubungan nasab dengan bapaknya. Anak itu hanya mempunyai hubungan nasab dengan ibunya. Bapaknya tidak wajib memberikan nafkah kepada anak itu, namun secara biologis ia tetap anaknya. Jadi hubungan yang 
timbul hanyalah secara manusiawi, bukan secara hukum. (b). Tidak ada saling mewaris dengan bapaknya, karena hubungan nasab merupakan salah satu penyebab kerwarisan. (c). Bapak tidak dapat menjadi wali bagi anak diluar nikah. Apabila anak diluar nikah itu kebetulan seorang perempuan dan sudah dewasa lalu akan menikah, maka ia tidak berhak dinikahkan oleh bapak biologisnya. (Sofwan, 1981).

Perbedaan perlindungan hukum antara anak dari hasil hubungan zina dengan anak dalam ikatan perkawinan, telah diterangkan dalam beberapa hadits sahih yang menentukan bahwa anak hasil hubungan zina tidak memiliki hubungan keperdataan dengan lelaki yang mengakibatkan kelahirannya. Nabi Muhammad Saw bersabda: "Anak adalah bagi yang empunya hamparan (suami), dan bagi pezina batu (tidak berhak mendapat anak yang dilahirkan dari hubungan di luar nikah melainkan diserahkan kepada ibunya). (HR. Bukhari-Muslim, Malik dan Abu Daud). Dalam kasus li'an dimana suami menuduh istri berzina, anak tidak ikut bapaknya dari segi nasab, tetapi ibunya. Sebagaimana hadits Abu Daud: "dan Rasul menetapkan agar anaknya tidak dinasabkan kepada seorang ayah pun." Dalam hadits Imam Ahmad, ditetapkan agar anak ikut si wanita atau ibunya.Mahkamah Konstitusi dalam hal ini telah melampuai permohonan yang sekedar menghendaki pengakuan hubungan keperdataan atas anak dengan bapak hasil perkawinan tapi tidak dicatatkan di KUA menjadi meluas mengenai hubungan keperdataan atas anak hasil hubungan zina dengan lelaki yang mengakibatkan kelahirannya. MUI menilai putusan MK ini sangat berlebihan, melampuai batas, dan bersifat "over dosis" serta bertentangan dengan ajaran Islam dan pasal 29 UUD 45.

Menurut Makruf, putusan MK itu memiliki konsekuensi yang sangat luas, termasuk mengesahkan hubungan nasab, waris, wali, dan nafkah antara anak hasil zina dan lelaki yang menyebabkan kelahirannya karenahal demikian tidak dibenarkan oleh ajaran Islam.Akibat nyata putusan MK, kini kedudukan anak hasil zina dijadikan sama dengan kedudukan anak yang lahir dari hubungan perkawinan yang sah, baik dari segi kewajiban memperoleh nafkah dan terutama hak waris.

Dengan demikian, sudah jelas putusan MK ini telah menyebabkan lembaga perkawinan menjadi kurang relevan apalagi sekedar pencatatannya, mengingat penyamaan hak antara anak hasil zina dengan anak hasil perkawinan yang sah. Hal ini sangat menurunkan derajad kesucian dan keluhuran Lembaga perkawinan, bahkan pada tingkat ekstrem dapat muncul pendapat tidak dibutuhkan lagi lembaga perkawinan karena orang tidak perlu harus menikah secara sah apabila dikaitkan dengan perlindungan hukum anak. Dampak negatif lainnya hadir dalam segi teknis dengan adanya putusan MK ini, maka keadaan itu semua berubah. Diakuinya anak luar kawin (hasil biologis) sebagai anak yang sah berarti akan 
mempunyai hubungan waris dengan bapak biologisnya. Hal ini berakibat pula adanya hubungan waris. Jadi, si anak berhak atas warisan ayahnya tersebut. Ini tentu saja merepotkan pembagian warisan yang dilakukan oleh notaris. Kondisi tersebut menimbulkan masalah apabila warisan sudah terlanjur dibagikan kepada anak yang sah dari perkawinan. Lalu tiba-tiba muncul anak luar kawin yang mengklaim dan membawa bukti bahwa dia juga anak biologis dari pewaris. Selain itu berdampak kepada jual beli harta warisan, misalnya berupa tanah. Kekhawatiran lain misalnya suatu waktu dalam pembuatan Akta Jual Beli, tetapi tiba-tiba datang anak luar kawin yang menuntut karena merasa mempunyai hak waris.

Dampak positif Putusan MK Nomor 46/PUU-VIII/2010 terbuka kesempatan bagi para anak diluar nikah untuk mendapatkan hak nafkah, waris dan lain sebagainya. Dampak negatifnya putusan Putusan MK Nomor 46/PUU-VIII/2010 dinilai melanggar ajaran Islam dan tatanan hukum Islam. Hukum Islam menyatakan bahwa, status anak diluar nikah dalam kategori yang kedua, disamakan statusnya dengan anak zina dan anak li'an. Dampak negatif lainnya hadir dalam segi teknis dengan adanya putusan MK ini, maka keadaan itu semua berubah dan merepotkan pembagian warisan yang dilakukan oleh notaris.Sebaiknya Mahkamah Konstitusi hanya mengabulkan permohonan pemberian status anak luar kawin dari pernikahan siri bukan anak dari hasil zina. Karena tentunya hal ini membawa dampak yang bukan hanya teknis tetapi ideologis dan akidah umat Islam

\section{KESIMPULAN}

Hak asasi manusia merupakan hak dasar yang dianugrahkan Allah swt kepada manusia, dan hak ini telah diakui secara universal sehingga sudah menjadi kewajiban agar perlindungan terhadap hak asasi manusia dapat terjaga dan terlaksana. Hak asasi manusia sangat melindungi hak hak anak terlepas dari sah tidaknya anak tersebut. Perlakuan diskriminatif terhadap hak-hak anak luar kawin tidak selaras dengan prinsip konsep Hak Asasi Manusia. Pasal 1 Deklarasi Universal Hak Asasi Manusia (DUHAM), Disebutkan bahwa semua orang dilahirkan merdeka dan mempunyai martabat dan hak-hak yang sama, mereka dikaruniai akal dan hati nurani dan hendaknya bergaul satu dengan yang lain dalam persaudaraan.Pasal 2 berbunyi bahwa setiap orang berhak atas semua hak dan kebebasan-kebebasan yang tercantum di dalam Deklarasi ini dengan tidak ada pengecualian apapun, seperti pembedaan ras, warna kulit, jenis kelamin, bahasa agama, politik atau kedudukan lain.

Negara menjunjung tinggi hak asasi manusia, termasuk di dalamnya hak asasi. Anak yang ditandai dengan adanya jaminan perlindungan dan pemenuhan. Hak Anak dalam Undang-Undang Dasar Negara Republik Indonesia Tahun 1945 
dan beberapa ketentuan peraturan perundang-undangan baik yang bersifat nasional maupun yang bersifat internasional. Salah satunya adalah UndangUndang Nomor 35 tahun 2014 tentang Perlindungan Anak. Undang-Undang Nomor 35 Tahun 2014 mengamanatkan bahwa Negara, pemerintah, Pemerintahan Daerah, Masyarakat, Keluarga, dan Orang tua berkewajiban untuk memberikan perlindungan menjamin terpenuhinya hak asasi anak sesuai dengan tugas dan tanggung jawabnya. Dalam melaksanakan upaya perlindungan terhadap hak anak oleh pemerintah harus didasarkan pada prinsip hak asasi manusia yaitu: penghormatan, pemenuhan dan perlindungan atas hak anak.

\section{REFERENSI}

Aimmah, Q. (2010). Implikasi Kewarisan atas pengakuan Anak Luar kawin (Studi Komparasi Antara Hukum Islam Dan Hukum Perdata / Burgerlijk wetboek). UIN Sunan Ampel.

Ala' ad-Din Abu Bakr bin Mas'ud al-kasaniy. (2003). Bada'I as-Sana (Juz III). Dar al-Kutubal 'ilmiyahy.

Busthanul Arifin. (1996). Pelembagaan Hukum Islam Di Indonesia. Gema Insani Press.

Djamil, N. (2013). Anak Bukan Untuk dihukum: Catatan Pembahsan UU Sistem Peradilan anak. Sinar Grafika.

Gultom, M. (2012). Perlindungan Hukum Terhadap anak dan perempuan. Refika Aditama.

Hasan Makluf. (1979). Al-Mawaris Fi Al-Syari'ah Al Islamiyah. Mathba'ah AlQahirah.

Husna, E. (2011). Pembagian Harta Warisan Anak Zina (Studi komparatif antara pendapat Syafi'i $n$ Ahmad bin Hambal).

Kasir, I. bin U. I. (1999). Tafsir Al-Quran Al-Azim (Juz VII). Darat-Taybah.

Lopa, B. (1996). Al-Qur'an dan Hak-Hak Asasi Manusia. Dana Bhakti Primajasa.

PBB, M. U. (1948). DEKLARASI UNIVERSAL HAK-HAK ASASI MANUSIA.

R.A. Koesnan. (2005). Susunan Pidana Dalam Negara Sosialis Indonesia. sumur.

Sofwan, S. S. M. (1981). Hukum Perdata, Hukum Benda. Liberty Yogyakarta.

Undang-undang No. 39 Tahun 1999 Tentang Hak Asasi Manusia. (n.d.).

Undang-Undang Nomor 23 Tahun 2014 Tentang perubahan atas Undang- 
Al-Mujtahid: Journal of Islamic Family Law Vol. 1, No. 1 (2021): 1-13

Website: http://journal.iain-manado.ac.id/index.php/almujtahid

Undang no 23 Tahun 2002 Tentang Perlindungan Anak. (n.d.).

W.J.S. Poerwadarmita. (1984). Kamus Umum Bahasa Indonesia. Balai Pustaka.

Wahbah Az-Zuhaili. (n.d.). Al Fiqh al-Islamiy wa Adillatuh (JUZ VII). 